\title{
Centrosome amplification in chondrosarcomas: A primary cell culture and cryopreserved tumor sample study
}

\author{
CARLA APARECIDA PINHEIRO ${ }^{1,2}$, IBERÊ CAUDURO SOARES ${ }^{1,3}$, VALTER PENNA $^{4}$, JEREMY SQUIRE $^{5}$, \\ RUI MANUEL VIEIRA REIS ${ }^{1,6}$, SANDRA REGINA MORINI DA SILVA ${ }^{1}$, ISABELA DE CARVALHO ${ }^{1}$, \\ MARJORI LEIVA CAMPAROTO ${ }^{1}$, MAICON FERNANDO ZANON DA SILVA ${ }^{1}$ and ADHEMAR LONGATTO FILHO ${ }^{6-9}$ \\ ${ }^{1}$ Barretos Cancer Hospital, Pio XII Foundation, Barretos, São Paulo 14780-000; ${ }^{2}$ Department of Orthopedics, \\ Faculty of Medicine, Federal University of Uberlândia, Uberlândia, Minas Gerais 38408-100; ${ }^{3}$ Department of Pathology, \\ Federal University of Santa Maria, Santa Maria 97105-900; ${ }^{4}$ Paulista State University, Botucatu, São Paulo 18607-741; \\ ${ }^{5}$ Department of Pathology and Forensic Medicine, Ribeirão Preto Medical School, University of São Paulo, Ribeirão Preto, \\ São Paulo 14049-900; ${ }^{6}$ Molecular Oncology Research Center, Barretos Cancer Hospital, Pio XII Foundation, Barretos, \\ São Paulo 14780-000; ${ }^{7}$ Laboratory of Medical Investigation 14, Faculty of Medicine, University of São Paulo, \\ São Paulo 01246-903, Brazil; ${ }^{8}$ Life and Health Sciences Research Institute 61, School of Health Sciences, \\ University of Minho, 4710-057 Braga; ${ }^{9}$ ICVS/3B's-PT Government Associate Laboratory, \\ Guimarães, 4710-070 Braga, Portugal
}

Received October 27, 2015; Accepted July 14, 2016

DOI: $10.3892 / \mathrm{ol} .2017 .5633$

\begin{abstract}
The genetics background underlying the aggressiveness of chondrosarcoma (CS) is poorly understood. One possible cause of malignant transformation is chromosomal instability, which involves an error in mitotic segregation due to numerical and/or functional abnormalities of centrosomes. The present study aimed to evaluate centrosome amplification in cryopreserved samples of tumor tissue from patients with CS. An analysis was performed on 3 primary cultures of tumors from patients who underwent surgery between January 2012 and December 2012 at the Department of Orthopedics at the Barretos Cancer Hospital (Barretos, Brazil). Additionally, cryopreserved tumor specimens were analyzed from 10 patients. The data were assessed using immunocytochemistry and immunohistochemistry staining techniques with monoclonal antibody anti- $\gamma$-tubulin. A total of 4 samples of CS cultured cells were obtained from 3 patients. A recurrence of a histological grade III tumor was detected in a female patient with Ollier's syndrome. The other 2 cases were grade I and III. The incidence of centrosome amplification in the primary cultures ranged from $15-64 \%$ of the cells. Whereas control cultured fibroblasts showed baseline levels of $4 \%$ amplified cells. For the cryopreserved specimens, two
\end{abstract}

Correspondence to: Dr Adhemar Longatto Filho, Laboratory of Medical Investigation 14, Faculty of Medicine, University São Paulo, 455 Avenida Dr. Arnaldo, Cerqueira César, São Paulo 01246-903, Brazil

E-mail: longatto16@hotmail.com

Key words: chondrosarcoma, centrosome amplification, primary cell culture independent observers analyzed each sample and counted the cells stained with $\gamma$-tubulin, verifying the percentage of affected cells to be a mean of $14 \%$, with the number of clusters ranging between $0-6$ per slide. In conclusion, centrosome amplification was found to be a consistent biological feature of CS and may underlie chromosomal instability in this tumor.

\section{Introduction}

Chondrosarcoma (CS) is a neoplasm of mesenchymal origin that forms cartilage-pattern tumors of the bone and consists of different histological subtypes (1).

This tumor is considered to be resistant to chemotherapy and radiotherapy, and the mainstay treatment is surgical $(2,3)$. Several attempts have been made to identify reliable molecular markers and therapeutic targets for CS. However, none of these biological markers have been proven to provide independent prognostic information (4-6).

The majority of genetic analyses performed on CS were performed on a heterogeneous group that included all different subtypes of CS; ploidy-analysis of CS has been described and aneuploidy is more frequently found in high-grade CS $(7,8)$.

There have been, to date, few studies on CS cell lines. This may be associated with the low proliferation rates of the tumor cells and the difficulty in reproducing an adequate environment for CS development (9).

The centrosome is a non-membranous organelle usually found in the periphery of the nucleus; it consists of a pair of orthogonally arranged, barrel-shaped centrioles and numerous different proteins that surround the pericentriolar material. During interphase, the centrosome is responsible for organizing the microtubule network by directing the formation of the mitotic spindle (10). It has been demonstrated that the centrosome amplification is linked to chromosomal instability and the 
prognosis of patients with malignant tumors (11). Centrosome amplification has been detected in several types of malignancies and borderline sarcomas, including osteosarcoma $(7,12,13)$. Moskovsky et al reported that centrosome amplification is present in benign giant cell tumors of the bone, demonstrating that this phenomenon is not characteristic of malignant giant cell tumors. In addition, the study showed that centrosome amplification was prognostic for clinical behavior (14).

The present study aimed to characterize centrosome amplification in CS using cryopreserved tissue samples and tissue cultures.

\section{Materials and methods}

Tumor samples. The study was conducted with cryopreserved CS tumor tissue samples from 10 patients treated surgically in the Barretos Cancer Hospital (Barretos, Brazil). Additionally, samples were used from the cultures of tumors from 3 patients who underwent surgery in the Department of Orthopedics at the Barretos Cancer Hospital. The study was approved by the Institutional Ethical Committee of the Barretos Cancer Hospital.

Establishment of primary cultures. In this study, centrosome amplification was evaluated in CS using cryopreserved tissues and primary cell cultures. A commercial culture of normal fibroblasts, lineage CCD-1059 SK, was used as a control (Thermo Fisher Scientific Inc., Waltham, MA, USA). The cells from the tumor samples were cultured for 7-25 days in an incubator with a humidified atmosphere containing 5\% $\mathrm{CO}_{2}$ at $37^{\circ} \mathrm{C}$, standing for $\sim 7$ days until confluence, prior to cytogenetic and morphological evaluation (Fig. 1).

Tumors were reviewed by a pathologist and graded and staged according to World Health Organization classification (1). Primary tumor specimens were finely minced, treated with trypsin and cultured in Dulbecco's modified Eagle's medium (Thermo Fisher Scientific Inc.) supplemented with $10 \%$ fetal bovine serum (Thermo Fisher Scientific Inc.) and 1\% antibiotics.

\section{Analysis of centrosome amplification}

Immunohistochemistry/immunocytochemistry. The cells were cultured on coverslips for 3-4 days, washed with phosphate-buffered saline, fixed with $4 \%$ paraformaldehyde and then permeabilized with Triton-X100. An UltraVision Plus detection system (Thermo Fisher Scientific Inc.) was used for centrosome immunostaining and analysis.

The cells were incubated overnight with mouse monoclonal anti- $\gamma$-tubulin (1:2,000 dilution; Sigma-Aldrich, St. Louis, MO, USA) and blocked with Ultra-V-Block (Thermo Fisher Scientific Inc.). All incubations were performed at $31^{\circ} \mathrm{C}$ with primary antibodies for $30 \mathrm{~min}$, and thereafter with the biotinylated secondary antibody (Thermo Fisher Scientific Inc.) for $60 \mathrm{~min}$. After 3,3'-diaminobenzidine exposure, the slides were subsequently stained with hematoxylin.

To determine centrosome numbers, the cells were subjected to immunostaining using a mouse monoclonal anti- $\gamma$-tubulin antibody (Sigma-Aldrich), as described previously (15).

Statistical analysis. The Lin coefficient of concordance (MedCalc Version 11.1.1.0; MedCalc Software bvba, Ostend, Belgium) was used, considering a $95 \%$ confidence interval,

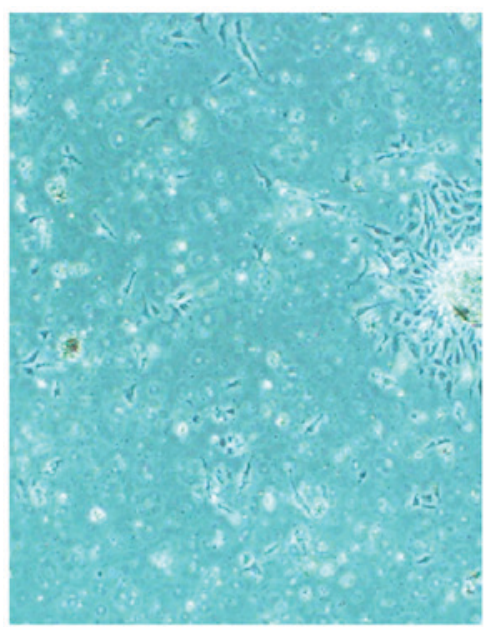

Figure 1. Establishment of primary chondrosarcoma cultures. Images obtained using an inverted microscope at x10 magnification. Trypan blue staining.

as it is a test that combines a measure of accuracy (Pearson correlation coefficient; MedCalc Version 11.1.1.0) with another measure of accuracy $(\mathrm{Cb})$ to determine how the observed data deviate from the line of identity (i.e., $45^{\circ}$ line), with variance based on to the distance of the data to the line (the accuracy of the data), and on the dispersion of the data around the line (data accuracy). Given the number of categories observed in the total score, the Lin concordance coefficient was also adopted to assess the degree of agreement between the two observers. For this coefficient, excellent agreement was defined as a value $>0.900$, a suitable value ranged from $0.600-0.900$ and an unsatisfactory value was $<0.600$.

\section{Results}

Primary cultures. Cultures from the tumor samples of 3 patients who underwent surgery in 2012 in Barretos Cancer Hospital were analyzed. The clinical data are summarized in Table I. Centrosome amplification was detected in the normal fibroblasts, with $5 \%$ of cells exhibiting increased numbers of centrosomes.

Following primary culture, to establish the patterning process, 2 of the samples were subjected to immunocytochemistry (Fig. 2A) and 1 samples was subjected to immunofluorescence (Fig. 2B) analysis, as indicated in Table II.

Centrosome amplification, assessed using the immunocytochemistry technique (Fig. 2A), was observed in $64 \%$ of grade III CS Ollier's syndrome cells and in $76 \%$ of cells from the recurrence in the same patient (case 1). Amplification occurred in $48 \%$ of the grade I cells (case 2). Using the fluorescence technique, amplification was observed in $15 \%$ of the grade III CS cells (case 3).

Cluster formation was also observed in the cultures. In case 1 , one cluster occurred in $15 \%$ of the cells and two clusters occurred in $2 \%$. In the recurrence, $16 \%$ of cells exhibited one cluster, $5 \%$ exhibited two clusters and $1 \%$ exhibited three clusters. In grade I CS, one cluster was observed in $5 \%$ of nuclei and two clusters were observed in $1 \%$ of nuclei. As observed using the immunofluorescence technique, $8 \%$ of cells in the grade III CS (case 4) exhibited one cluster. 
Table I. Clinical data of patients with sarcoma who underwent surgery in the Department of Orthopedics at the Barretos Cancer hospital.

\begin{tabular}{|c|c|c|c|c|c|}
\hline Case & Gender/age, years ${ }^{\mathrm{a}}$ & Location & $\mathrm{Ch} / \mathrm{Rd}^{\mathrm{b}}$ & Pathology & Recurrence \\
\hline 1 & $\mathrm{~F} / 35$ & Left humerus & Yes/no & CS-Ollier's syndrome grade III & Yes \\
\hline 2 & $\mathrm{~F} / 50$ & Left distal femur & No/no & CS grade I & No \\
\hline 3 & $\mathrm{M} / 42$ & $\begin{array}{l}\text { Left shoulder and } \\
\text { suprascapular region }\end{array}$ & No/no & CS grade III & No \\
\hline
\end{tabular}

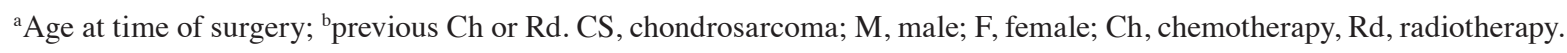

Table II. Frequency of centrosome amplification in primary cultures of CS.

\begin{tabular}{|c|c|c|c|c|c|}
\hline \multirow[b]{2}{*}{ Subtype } & \multicolumn{2}{|c|}{ Presence of centrosomes per cell $(\%)$} & \multicolumn{3}{|c|}{ Clusters $(\%)$} \\
\hline & Normal & Amplified & 1 Cluster & 2 Clusters & 3 Clusters \\
\hline CS-Ollier's syndrome grade III & 36 & 64 & 15 & 2 & 0 \\
\hline $\begin{array}{l}\text { CS-Ollier's syndrome grade III } \\
\text { (sample of recurrence) }\end{array}$ & 24 & 76 & 16 & 5 & 1 \\
\hline CS grade I & 52 & 48 & 5 & 1 & 0 \\
\hline CS grade III & 85 & 15 & 8 & 0 & 0 \\
\hline
\end{tabular}

CS, chondrosarcoma.

A

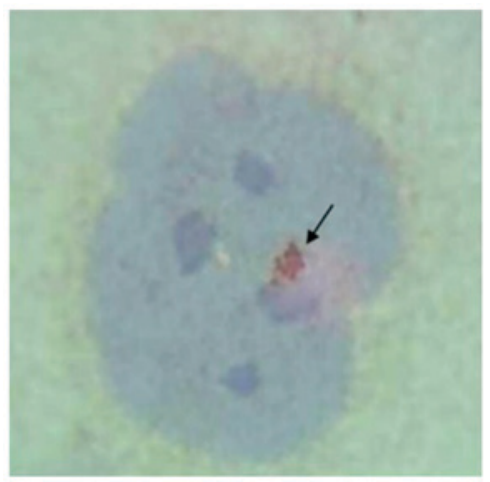

B

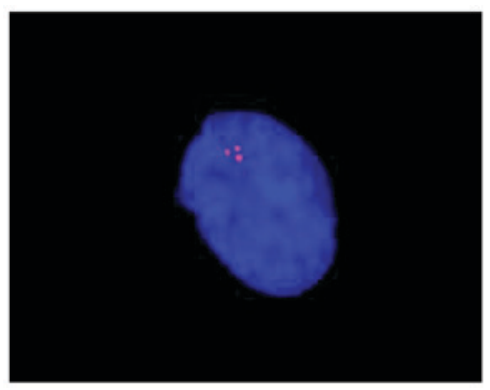

Figure 2. Primary chondrosarcoma culture (control) images (x1,000 magnification), as determined by (A) immunocytochemistry (arrow indicates a cluster of centrosomes) and (B) immunofluorescence analysis.

A commercial culture of normal fibroblasts (CCD-1059 SK lineage) was also established that served as a negative control; the amplification of centrosomes was observed in $5 \%$ of the control cells, as observed using immunocytochemistry.
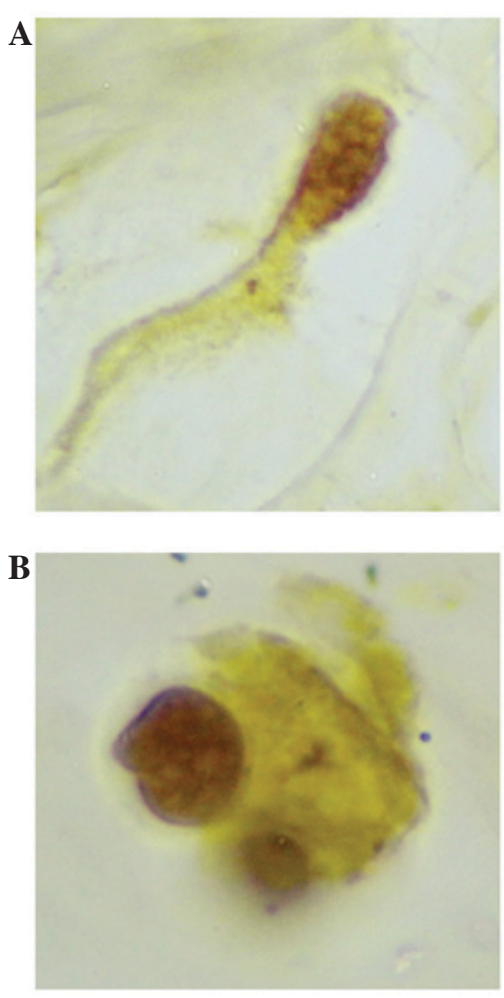

Figure 3. Cryopreserved materials immunohistochemically-stained for $\gamma$-tubulin (optical microscopy, x200 magnification). (A) Case 9: Secondary, grade I. (B) Case 5: Primary myxoid, grade I.

Cryopreserved tissue. A total of 10 samples of cryopreserved CS tumor tissue samples stored in the tumor bank were 
Table III. Main clinical data of the cryopreserved tissue using immunohistochemistry.

\begin{tabular}{|c|c|c|c|c|c|c|c|c|}
\hline Case & $\begin{array}{l}\text { Gender } \\
\text { /age, years }\end{array}$ & $\begin{array}{l}\text { Follow-up } \\
\text { time, } \\
\text { months }\end{array}$ & Location & Pathology & Metastasis & Surgical type & $\begin{array}{l}\text { Functional } \\
\text { status of } \\
\text { the member }\end{array}$ & Last information \\
\hline 1 & $\mathrm{M} / 65$ & 29.31 & Pelvis & $\begin{array}{l}\text { Classical grade } \mathrm{I}, \\
\text { primary }\end{array}$ & $\begin{array}{l}\text { Yes, after } \\
\text { diagnosis }\end{array}$ & $\begin{array}{l}\text { Simple } \\
\text { resection }\end{array}$ & $\begin{array}{l}\text { With } \\
\text { limitation }\end{array}$ & $\begin{array}{l}\text { Succumbed to } \\
\text { cancer }\end{array}$ \\
\hline 2 & $\mathrm{~F} / 56$ & 65.08 & Chest & $\begin{array}{l}\text { Classical grade I, } \\
\text { primary }\end{array}$ & No & $\begin{array}{l}\text { Simple } \\
\text { resection }\end{array}$ & $\begin{array}{c}\text { Not } \\
\text { applicable }\end{array}$ & $\begin{array}{l}\text { Alive without } \\
\text { disease }\end{array}$ \\
\hline 3 & $\mathrm{~F} / 21$ & 9.66 & Pelvis & $\begin{array}{c}\text { Classical grade II, } \\
\text { primary }\end{array}$ & $\begin{array}{c}\text { Yes, } \\
\text { at diagnosis }\end{array}$ & $\begin{array}{c}\text { Not } \\
\text { operated }\end{array}$ & Unknown & $\begin{array}{l}\text { Alive without } \\
\text { disease }\end{array}$ \\
\hline 4 & $\mathrm{~F} / 41$ & 39.39 & $\begin{array}{l}\text { Lower } \\
\text { limb }\end{array}$ & $\begin{array}{l}\text { Myxoid grade I, } \\
\text { primary }\end{array}$ & $\begin{array}{c}\text { Yes, } \\
\text { at diagnosis }\end{array}$ & Amputated & Amputated & $\begin{array}{l}\text { Alive without } \\
\text { disease }\end{array}$ \\
\hline 5 & $\mathrm{~F} / 52$ & 65.41 & Pelvis & $\begin{array}{l}\text { Myxoid grade I, } \\
\text { primary }\end{array}$ & No & $\begin{array}{c}\text { Simple } \\
\text { resection }\end{array}$ & Functional & $\begin{array}{l}\text { Alive without } \\
\text { disease }\end{array}$ \\
\hline 6 & $\mathrm{~F} / 46$ & 38.44 & $\begin{array}{l}\text { Shoulder } \\
\text { girdle }\end{array}$ & $\begin{array}{c}\text { Classical grade II, } \\
\text { secondary }\end{array}$ & No & $\begin{array}{l}\text { Simple } \\
\text { resection }\end{array}$ & Functional & $\begin{array}{l}\text { Alive without } \\
\text { disease }\end{array}$ \\
\hline 7 & $\mathrm{M} / 27$ & 42.25 & $\begin{array}{l}\text { Upper } \\
\text { limb }\end{array}$ & $\begin{array}{l}\text { Classical grade I, } \\
\text { secondary }\end{array}$ & No & Amputated & Amputated & $\begin{array}{l}\text { Alive without } \\
\text { disease }\end{array}$ \\
\hline 8 & $\mathrm{~F} / 37$ & 30.46 & $\begin{array}{l}\text { Lower } \\
\text { limb }\end{array}$ & $\begin{array}{c}\text { Classical grade II, } \\
\text { secondary }\end{array}$ & No & $\begin{array}{l}\text { Resection and } \\
\text { prosthesis }\end{array}$ & $\begin{array}{l}\text { With } \\
\text { limitation }\end{array}$ & $\begin{array}{c}\text { Alive without } \\
\text { disease }\end{array}$ \\
\hline 9 & $\mathrm{~F} / 25$ & 1.05 & $\begin{array}{l}\text { Shoulder } \\
\text { girdle }\end{array}$ & $\begin{array}{l}\text { Classical grade I, } \\
\text { secondary }\end{array}$ & No & $\begin{array}{l}\text { Simple } \\
\text { resection }\end{array}$ & Functional & $\begin{array}{c}\text { Alive without } \\
\text { disease }\end{array}$ \\
\hline 10 & $\mathrm{M} / 42$ & 17.74 & $\begin{array}{l}\text { Shoulder } \\
\text { girdle }\end{array}$ & $\begin{array}{c}\text { Classical grade III, } \\
\text { primary }\end{array}$ & $\begin{array}{c}\text { Yes, } \\
\text { at diagnosis }\end{array}$ & Amputated & Amputated & $\begin{array}{l}\text { Alive without } \\
\text { disease }\end{array}$ \\
\hline
\end{tabular}

Table IV. Frequency of centrosome amplification and the frequency of clusters in 10 cryopreserved chondrosarcoma tissues (analysis conducted by two independent observers).

\begin{tabular}{ccccc}
\hline & \multicolumn{2}{c}{ Percentage frequency of centrosome amplification } & & \multicolumn{2}{c}{ Number of clusters of centrosomes } \\
\cline { 2 - 2 } \cline { 5 - 5 } Case & Analyst A (\%) & Analyst B (\%) & Analyst A & Analyst B \\
\hline 1 & 18.0 & 22.0 & 0 & 0 \\
2 & 21.0 & 20.0 & 3 & 6 \\
3 & 13.9 & 6.9 & 1 & 0 \\
4 & 9.3 & 9.3 & 0 & 1 \\
5 & 19.0 & 20.0 & 1 & 0 \\
6 & 17.0 & 13.0 & 2 & 0 \\
7 & 10.0 & 10.0 & 0 & 0 \\
8 & 16.0 & 13.0 & 0 & 1 \\
9 & 14.0 & 11.0 & 1 & 0 \\
10 & 4.0 & 10.0 & & 0 \\
\hline
\end{tabular}

selected. The clinical data of the 10 patients who provided these samples are summarized in Table III.

Centrosome amplification. The centrosomes were analyzed using an optical microscope (x1,000 magnification). Two independent observers analyzed each sample and counted the cells stained with $\gamma$-tubulin, verifying the percentage of affected cells (Fig. 3).

The results are shown in Table IV. Analyst A found the percentage of cells with amplifications ranged between 4 and $19 \%$ (mean, 14\%), while analyst B found that the percentage of cells with amplification ranged between 7 and $22 \%$ (mean, 14\%).

With regard to the formation of clusters, analyst A found 0-3 clusters per slide (mean, 0.8 clusters) and analyst B found between 0 and 6 clusters (mean, 1 cluster).

Data analysis. For the 10 cases evaluated, the data were analyzed using the Lin concordance coefficient. With regard to the percentage of cells with amplification, the estimates ranged from $0.2205-0.9211$ with $95 \%$ confidence. The concordance correlation coefficient was 0.7213 . 
With regard to the number of clusters, the data were analyzed using the Lin concordance coefficient, and with 95\% confidence, it is estimated that the range was from 0.4948-0.8861. The concordance correlation coefficient was 0.7500 .

\section{Discussion}

The data in the present study revealed that the CS genetic profile adopts several alterations associated with centrosome amplification, as previously supposed (10-12). The present study describes arguments in favor of the premise that centrosome amplification is a critical biological event for the development of this malignancy. The study of centrosome alterations is multifaceted and time consuming, and accordingly requires appropriate expertise of the professionals involved and tests to evaluate the results. The technical procedures to maintain primary cultures of cancer offer varying degrees of difficulty and so the results are not always satisfactory. Sarcoma cultures are even more complex and difficult to effectively conduct. Therefore, the establishment of primary cultures of CS produces a working model that is quite promising. In the present study, the primary cultures of CS were prepared using samples from three cases with different histopathological classifications: 1 grade I case, 1 grade III case and 1 grade III case with CS recurrence.

In general, the findings demonstrated that in the cases of primary cultures stained with the immunocytochemistry technique using fluorescent development, the assessment of centrosomes was clear, without any ill-defined images. The amplified centrosomes were positively demonstrated in all cases when compared with normal fibroblasts, with demonstrated percentages of amplified centrosomes ranging from 15-64\%. Notably, even the grade I CS showed amplified centrosomes, implying that the amplification of centrosomes can be hypothesized as a precursor to malignant transformation. A sample of recurrent tumor revealed amplified centrosomes, as was previously observed in the primary CS sample of the same patient, but with an increased number of malignant cells with more than two centrosomes. Another case exhibited a low rate of centrosome amplification, showing only $15 \%$ of cells with amplification. This finding is not unexpected, as centrosome amplification in bone and soft tissue tumors has been observed in tumors classified as benign or with local aggressiveness (as in giant cell tumors) or even in malignant bone tumors such as osteosarcoma (14).

Analysis of the cryopreserved tissues showed amplification percentages ranging from 4-19\% (mean, 14\%), which is lower compared with the primary culture. This difference may be due to the quality of the sample, and the fact that the primary culture tended to be the most similar to the tumor in vivo. The presence of centrosome amplification can also be represented by the formation of clustering, but the mechanism is not fully understood. Abnormalities in centrosome organization are under investigation in oncology settings and the findings have been observed in in vivo samples and cultured cells (12). In the present study, 2 cases showed single clusters occurring in 15 and $16 \%$ of the cells, respectively, compared with the normal fibroblasts, which showed a maximum of 3\%. However, a reduced number of clusters was also observed in CS, with 1 case exhibiting $5 \%$ of malignant cells with one cluster and $1 \%$ of malignant cells with two clusters. The remaining case showed only $8 \%$ of malignant cells with one cluster each.
This significant variation in centrosome clusters suggests that cluster formation is not a pivotal phenomenon for CS behavior. Setoguchi et al observed similar findings in sarcomas of dogs (16). Different types of sarcomas have shown hyperamplification of centrosomes associated with chromosome instability, which was credited as a novel tumor marker (12).

In this study, cryopreserved tissues in the percentages of clusters were smaller than those found in culture, ranging from 1 to $6 \%$ of cells with clusters. This difference may be occurring due to the characteristic of the sample; the cell culture would be the closest representation of the tumor in vivo. Another fact that was found is that the clusters found in the cryopreserved tissues were smaller than those in the cell cultures.

Centrosome amplification may predict the aggressive behavior of tumors, and other findings in the literature have associated this process with an alteration of centrosomes, with chromosomal instabilities found in other bone tumors such as osteosarcoma, as anticipated (12). The present results support these premises and concur that centrosome amplification is widely found in CS and likely represents a major mechanism underlying the generation of multipolar mitoses, chromosome instabilities and aneuploidy.

\section{References}

1. Fletcher CDM, Bridge JA, Hogendoorn PCW and Mertens F (eds): World Health Organization Classification of Tumours: Pathology and Genetics of Tumors of Soft Tissue and Bone. IARC Press, Lyon, 2002.

2. Heck RKJ: Malignant tumors of the bone. In: Campbells Orthopedic Surgery. pp827-858, 2006 (In Portuguese).

3. Própero D: Producers neoplasms of cartilaginous tissue. In: Bone Tumors. ROCA, São Paulo, Brazil, pp45-91, 2001 (In Portuguese).

4. Chow WA: Update on chondrosarcoma. Curr Opin Oncol 19: 371-376, 2007.

5. Jamil N, Howie S and Salter DM: Therapeutic molecular target in human chondrosarcoma. Int J Exp Pathol 91: 387-393, 2010.

6. Onishi AC, Hincker A and Lee FY: Surmounting chemoterapy and radioresistance in chondrosarcoma: Molecular mechanisms and therapeutic targets. Sarcoma 2011: 381564, 2010.

7. Gisselsson D, Pålsson E, Yu C, Mertens F and Mandahl N: Mitotic instability associated with late genomic changes in bone and soft tissue tumors. Cancer Lett 206: 69-76, 2004.

8. Kim MJ, Cho KJ, Ayala AG and Ro JY: Chondrosarcoma: With updates on molecular genetics. Sarcoma 2011: 405437, 2011.

9. Monderer D, Luseau A, Bellec A, et al: New chondrossarcoma cell lines and mouse models to study the link between chondrogenesis and chemoresistence. Lab Invest: 1100-1114, 2013.

10. Fukasawa K: Aberrante activation of cell cycle reguators, centrossome amplification, and mitotic defects. Horm Cancer 2: 104-112, 2010.

11. Chan JY: A clinical overview of centrossome amplication in human cancers. Int J Biol Sci 7: 1122-1144, 2011.

12. Al-Romaih K, Bayani J, Vorobyova J, et al: Chromosomal instability in osteosarcoma and its association with centrosome abnormalities. Cancer Genet Cytogenet 144: 91-99, 2003.

13. Perucca-Lostanlen DRP, Grosgeorge J, Marcie S, Gaudray P and Turccarrel C: Distinct MDM2 and PI4ARF expression and centrosome amplification in well-differentiated liposarcomas. Genes Chrom Canc 39: 99-109, 2004.

14. Moskovszky L, Dezsö K, Athanasou N, Szendröi M, Kopper L, Kliskey K, Picci P and Sápi Z: Centrossome abnormalities in giant cell tumour of bone: Possible association with chromosomal instability. Mod Pathol 23: 359-366, 2010.

15. Yamamoto Y, Misumi T, Eguchi S, et al: Centrosome amplification as a putative prognostic biomarker for the classification of urothelial carcinomas. Hum Pathol, 42: 1923-1930, 2011.

16. Setoguchi A, Okuda M, Nishida E, et al: Results of hyperamplification of centrosomes in naturally developing tumors of dogs. Am J Vet Res 62: 1134-1141, 2001. 